\title{
Growth and Anatomical Alterations in Leaves of Popcorn Induced by Abiotic Stresses
}

\author{
Claudia B. Trevizan ${ }^{1}$, Hélida M. Magalhães ${ }^{1} \&$ Silvia G. H. de Souza ${ }^{1}$ \\ ${ }^{1}$ Programa de Pós-graduação em Biotecnologia Aplicada à Agricultura, Universidade Paranaense, Umuarama, \\ Brazil \\ Correspondence: Silvia G. H. de Souza, Programa de Pós-graduação em Biotecnologia Aplicada à Agricultura, \\ Universidade Paranaense, Praça Mascarenhas de Moraes, 4282, Umuarama, PR, Brazil. E-mail: \\ silviahulse@prof.unipar.br
}

$\begin{array}{lc}\text { Received: July 18, 2018 } & \text { Accepted: August 26, 2018 Online Published: October 15, } 2018 \\ \text { doi:10.5539/jas.v10n11p349 } & \text { URL: https://doi.org/10.5539/jas.v10n11p349 }\end{array}$

The research is financed by Universidade Paranaense.

\begin{abstract}
Stress by salt and aluminum $\left(\mathrm{Al}^{+3}\right)$ causes significant loss in the growth of popcorn. Effects on the initial growth, especially of leaves and stomata, are poorly investigated, while no information is available for some cultivars. This work aims at verifying the effect of stress caused by salt and $\mathrm{Al}^{+3}$ on the initial growth, morphometry, and morphology of popcorn stomata (IAC-125), as well as on its foliar anatomy. In the presence of $50 \mathrm{mM}$ or higher concentrations of $\mathrm{NaCl}$, popcorn seedlings showed a reduction of $50 \%$ in shoot mass gains as compared to the control. With $150 \mathrm{mM}$ or higher concentrations, mass gains reduced by $33 \%$ in popcorn root system as compared to the control. Small increases in shoot length were observed in seedlings treated with $\mathrm{Al}^{+3}$. The root system was highly affected by $160 \mu \mathrm{M}$ or higher $\mathrm{Al}^{+3}$ concentrations. Pore opening and stomatal subsidiary cell width were altered under both salt and $\mathrm{Al}^{+3}$ stress. Stomatal density changes were observed only under salt stress. Tissue disruptions and cell numberreductions were verified in the epidermis and parenchyma under high $\mathrm{Al}^{+3}$ and saltconcentrations. The largest xylem and phloem cells were preserved in all treatments. Stress resulted in dehydration of plant tissues, which showed retraction under high concentrations of salt and $\mathrm{Al}^{+3} \mathrm{due}$ to anatomical changes in the leaves and morphometry of the stomata. Our results demonstrated that these characteristics contributed to a remarkable tolerance to salinity and aluminum, since they have an important protective role against different environmental stresses.
\end{abstract}

Keywords: aluminum, parenchyma, Poaceae, salinity, stomata, Zea mays L.

\section{Introduction}

Corn (Zea mays L.) contributes to the diets of many people around the world (Arendt \& Zannini, 2013) and forms the nutritional basis of animal feed, mainly poultry, pork, and beef. Being a member of the Poaceae family, corn is a crop of great economic importance. Unlike common corn, popcorn has small, hard grains that have the capacity to burst when heated to around $180^{\circ} \mathrm{C}$ (Sawazaki, 2001). Research and Markets have reported that the global popcorn market is expected to grow by 7.52\% over the period 2017-2021 (Global Popcorn Market, 2017). Popcorn is rich in fiber and carbohydrates, and has extensive amounts of antioxidants (polyphenols) that promote good gastrointestinal function (American Chemical Society, 2012; Lago et al., 2013). It is also rich in minerals, such as magnesium, manganese, phosphorus, zinc, copper, iron, and good fats, such as monounsaturated and polyunsaturated fats (Amercian Chemical Society, 2012).

Information available on the genetics and physiology of popcorn is very different from what is known about common corn, particularly regarding relevant production technologies in emerging countries (Oliveira et al., 2009). The cultivation of popcorn is commonly artisanal, i.e., without adapted cultivars and appropriate production techniques (Sawazaki, 2001). One of the problems faced by popcorn growers is the production loss caused by excess salt and aluminum $\left(\mathrm{Al}^{3+}\right)$ in soil (Gomes et al., 2011). Food and Agriculture Organization of the United Nations (FAO) published a report in 2015 that elaborated the situation of the world's soils; $33 \%$ of the soils were reported to have problems of salinization and acidification (Food and Agriculture Organization of the 
United Nations [FAO], 2015). The situation is alarming because many regions with such endangered soils have great agricultural aptitudes (FAO, 2015), such as areas in Brazil and some countries in Africa.

Salinity may be a consequence of inadequate fertilization and irrigation, deforestation, or may be naturally occurring (Silva, Grzybowsli, \& Panobiano, 2016). Excess salt causes severe morphological, physiological, and biochemical changes in plants (Silva et al., 2013). In addition, the accumulation of $\mathrm{Na}^{+}$and/or $\mathrm{Cl}^{-}$ions in chloroplasts under salt stress may inhibit photosynthesis (Parihar, S. Singh, R. Singh, P. Singh \& Prasad, 2015). Stress caused by toxic $\mathrm{Al}^{3+}$ ions is considered to be the biggest problem contributing toward acidic soils ( $\mathrm{pH}<$ 5.5) (Sade et al., 2016). The first plant response to $\mathrm{Al}^{3+}$ stress is inhibition of root growth (S. Dipierro, Mondelli, Paciolla, Brunetti, \& N. Dipierro, 2005), limited nutrient and water uptake, and reduced production (Lenoble et al., 2000; Sade et al., 2016). Studies show that $\mathrm{Al}^{3+}$ also induces a decrease in chlorophyll content, photosynthetic rate, stomatal conductance, and leaf transpiration (Ali et al., 2008; Ribeiro et al., 2013). In addition, acidic soils are less fertile because $\mathrm{Al}^{3+}$ reduces the availability of phosphorus, sulfur, and other cations to plants (Sade et al., 2016; Singh et al., 2017).

Most studies on salt and $\mathrm{Al}^{3+}$ as stress factors describe the damages they may incur to the enzymatic system (Boscolo, Menossi \& Jorge, 2003), alterations in primary metabolites (Richter et al., 2015; Pidatala, Li, Sarkar, Wusirika, \& Datta, 2018), and changes in gene expression (Cançado et al., 2008; Geilfus, Ludwig-Müller, Bárdos, \& Zörb, 2018; Manoli, Trevisan, Quaggioti, \&Varotto, 2018) in traditional corn cultivars. However, there are no consistent and conclusive reports on the effects of salt and $\mathrm{Al}^{3+}$ on the growth, physiology, and especially on the leaf anatomy of popcorn during the early stages of plant development. Research on $\mathrm{Al}^{3+}$ is extensive only for its toxicity effects on root systems (Pellet et al., 1995; Boscolo et al., 2003; Bennet, Breen, \& Fey, 2013) with only a few reports on the damage it can cause to the shoots and leaves.

Popcorn's early growth is severely altered by irrigation with saline water. Values above $2.13 \mathrm{dSm}^{-1}$ have been reported to be detrimental to stem growth (Oliveira et al., 2009). Excessive amounts of salts in the soil increase the levels of sodium in the form of higher $\mathrm{Na}^{+} / \mathrm{Ca}^{2+}, \mathrm{Na}^{+} / \mathrm{Mg}^{2+}$, and $\mathrm{Na}^{+} / \mathrm{K}^{+}$ratios, while reducing calcium, magnesium, and potassium contents. This creates a nutritional imbalance that hampers the development of traditional corn plants (Garcia et al., 2007). In the common corn root system, Boscolo et al. (2003) reported that stress caused by $\mathrm{Al}^{+3}$ may vary from species to species. According to these authors, corn plants that are in a state of responding to $\mathrm{Al}^{3+}$ stress present cell death in their root systems along with the presence of brown nuclei in their roots, which indicates high chromatin fragmentation.

Excess salt and $\mathrm{Al}^{3+}$ can hamper the growth, productivity, and quality of the popcorn grain in a multitude of ways. According to Lacerda et al. (2011) and Effa, Uwah, Iwo, Obo and Ukoha (2012), excessive concentrations of salt and $\mathrm{Al}^{3+}$ can reduce the productivity of popcorn and corn by $15-20 \%$ by interfering directly with their development (Lacerda et al., 2011; Effa et al., 2012). A reduced growth of the shoots and roots of popcorn plants is expected with increased concentrations of salt and $\mathrm{Al}^{3+}$ (Oliveira et al., 2009). Leaves can morpho-anatomically change to have an increased number of cells in the tissue or a reduced cell size, mainly in the parenchyma (Acosta-Moto et al., 2017). Such abnormal conditions make plants susceptible to disease and pest attacks, which further interrupts their growth in the field. Changes in the stomatal arrangement, density, and opening can occur in leaves, altering the efficiency of water use by plants (Parihar et al., 2015). Other leaf tissues in popcorn can also be affected, such as epidermis and conducting vessels (xylem and phloem) (Parihar et al., 2015; Acosta-Moto et al., 2017). Responses vary according to species and cultivars; therefore, the abovementioned effects cannot be generalized, and genotype-environment interactions should be considered in comparative research. The IAC-125 cultivar used in this study was recently adopted in popcorn-planting areas of Brazil. Therefore, there is very little information about its performance and stress response (Sawazaki, 2001).

Crop species are either tolerant or responsive to stress factors and have different tolerance levels. While lethal levels of $\mathrm{Al}^{+3}$ adversely affect some plants, others can be tolerant to such salt concentrations; this relationship largely varies among different plant species (Parida \& Das, 2005). Testing different concentrations of salt and $\mathrm{Al}^{+3}$ allow identifying the plants tolerance limit to such stress factors in addition to verifying their toxicity to each species studied. Such investigations allow understanding of plants behavior in adverse conditions and consequences on their development and production (Parihar et al., 2015; Acosta-Moto et al., 2017). A plant can combine several mechanisms for both tolerance and escape from stress (Parihar et al., 2015; Acosta-Moto et al., 2017). It does so by altering homeostasis to adapt to external environmental changes, which results in different morphological, anatomical, physiological, and biochemical expression (Kapoor et al., 2015).

Studies on different types of stress and on growth, development and metabolism of corn plants have gained high momentum. It has been reported that each type of stress differently influences plant metabolism of common corn 
(Boscolo et al., 2003; Garcia et al., 2007; Cançado et al., 2008; Geilfus, Ludwig-Müller, Bárdos, \& Zörb, 2018). However, few studies have demonstrated the effect of abiotic stress on the development and metabolism of popcorn (Oliveira et al., 2009). Therefore, this study aimed to verify the effects of salt and $\mathrm{Al}^{+3}$ stress on the early growth, morphometry, and morphology of stomata and leaf anatomy in popcorn plants.

\section{Material and Methods}

\subsection{Plant Material}

The experiment was carried out in the Plant Tissue Culture Laboratory of the Paranaense University (UNIPAR), in Umuarama/PR, Brazil. IAC-125 popcorn genotype seeds were germinated in growth chambers at $25 \pm 2{ }^{\circ} \mathrm{C}$, $200 \mu \mathrm{mol} \mathrm{m} \mathrm{s}^{-1}$ lighting intensity, and $60 \pm 5 \%$ relative humidity.

Two independent assays were conducted. In the first assay, seeds were sowed in $350 \mathrm{~mL}$ pots containing a commercial substrate (Carolina Padrão $\left.{ }^{\circledR}\right)$. Seedlings were irrigated daily with $\mathrm{NaCl}$ at concentrations of $0 \mathrm{mM}$ (control), $50 \mathrm{mM}, 100 \mathrm{mM}, 150 \mathrm{mM}$, and $200 \mathrm{mM}$ and every four days with Hoagland and Arnon solutions (Hoagland \& Arnon, 1950). In the second assay, seeds were sowed in modified Leonard pots (Santos et al., 2009) containing a substrate composed of washed sand and macerated charcoal in a 3:2 ratio $(\mathrm{v} / \mathrm{v})$; this substrate had been autoclaved at $121{ }^{\circ} \mathrm{C}$ for $1 \mathrm{~h}$. After planting seeds, $\mathrm{Al}_{2}\left(\mathrm{SO}_{4}\right)_{3} \cdot(14-18) \mathrm{H}_{2} \mathrm{O}$ was added to the Hoagland and Arnon solution (Hoagland \& Arnon, 1950) at concentrations of $0 \mathrm{mM}$ (control), $80 \mu \mathrm{M}, 160 \mu \mathrm{M}$, and $240 \mu \mathrm{M}$. Solutions were restored every four days with the appropriate concentrations as per the treatments. Plants were harvested at the $14^{\text {th }}$ day after the onset of stress in both assays, i.e., at the beginning of the seedlings' decline.

\subsection{Morphological Evaluation}

\subsubsection{Plant Height and Fresh Mass of Roots and Shoots}

Shoot and root heights $(\mathrm{cm})$ were determined with a tape measure, starting from the lap of the plant to the shoot and root tips. Shoot and root fresh masses (g) were weighed on an analytical balance.

\subsection{Foliar Anatomy}

\subsubsection{Analysis of Stomata}

Fully expanded leaves from the plants middle third section were collected 14 days after the onset of stress. Stomata were analyzed in the adaxial and abaxial parts of the leaves by preparing slides with the printing technique described by Segatto et al. (2004). Three replicates with ten areas of $1 \mathrm{~mm}^{2}$ each were used in each treatment. Photos were taken of the slides under an Olympus BX-60 microscope. Images were captured by Motic Images Plus 3.0 software. The following stomatal measures were recorded: Density $\left(\mathrm{mm}^{2}\right)$, pore aperture $(\mu \mathrm{m})$, and length and width of the subsidiary cells $(\mu \mathrm{m})$. Measurements were taken using the Image J. software (Rasband, 1997).

\subsubsection{Anatomical Analysis}

Foliar samples from each treatment were fixed in a formalin-50\% ethanol-acetic acid (FAA 50, 1:1:18 v/v) solution for $24 \mathrm{~h}$ and stored in $70 \%$ ethanol (Johansen, 1940). To allow the FAA solution to penetrate, the fixed tissues were completely dehydrated in a series of increasingly concentrated ethanol solutions (butyl series) and then embedded in wax (Paraplast Plus) (Kraus \& Arduin, 1997). The Leica (RM2125 RT) Biosystems ${ }^{\circledR}$ microtome was adjusted to cut each section with a thickness of $7 \mu \mathrm{m}$ at the Histotechnical Laboratory of Pathology. The sections were placed in a water bath at $45^{\circ} \mathrm{C}$ and removed on glass slides. To remove excess paraplast, slides with the fixed tissue were then placed in a water bath containing butyl acetate to be dehydrated in butyl series ethanol. Slides were stained with safrablau and a blend of astra blue and safranin $(9: 1, \mathrm{v} / \mathrm{v})$ (Bukatsch, 1972) followed by modification according to the method of Antoniazzi et al. (2016). Finally, glass varnish was applied to ensure adherence of the coverslip (Paiva, 2006).

Three replicates with 10 slides each were prepared per treatment. Photographs were taken under an Olympus BX-60 microscope and images were captured using the Motic Images Plus 3.0 software. The following tissues were analyzed: Epidermis, parenchyma, and conducting vessels.

\subsection{Experimental Design and Statistical Analysis}

\subsubsection{Data Analysis for Biometric Assessments}

A completely randomized design was applied to both assays; the first set of five treatments (i.e., 0, 50, 100, 150, and $200 \mathrm{mM} \mathrm{NaCl}$ ) and the second set of four treatments (i.e., 0, 80, 160, and $240 \mu \mathrm{M} \mathrm{Al}_{2}\left(\mathrm{SO}_{4}\right)_{3} \cdot(14-18) \mathrm{H}_{2} \mathrm{O}$ ) tested here were both done with three repetitions. Inhibition (\%) of biometric features was calculated in response to salt and $\mathrm{Al}^{+3}$ concentrations (Melo et al., 2017): 


$$
\text { Inhibition }(\%)=\frac{\text { control sample } \mathrm{i}-\text { sample } \mathrm{i}}{\text { control mean }} \times 100
$$

Data recorded for biometric features were submitted to the Shapiro-Wilk normality test. Non-normally distributed data was submitted to Kruskal-Wallis test at $\mathrm{p} \leq 0.05$ with the Assistatv.7.7 software. Normally distributed data was submitted to ANOVA at $\mathrm{p} \leq 0.05)$, and means were compared by Tukey test at $\mathrm{p} \leq 0.05$ with the SISVAR 5 software (Ferreira, 2011).

\subsubsection{Data Analysis for Anatomical Assessments}

At the end of the test, the final mean values of the observations were arranged in bar charts. Means were analyzed in a $2 \times 4$ factorial scheme for data from the two leaf faces (adaxial and abaxial) of seedlings submitted to four concentrations of $\mathrm{Al}^{+3}: 0,80,160$, and $240 \mu \mathrm{M} \mathrm{Al}{ }_{2}\left(\mathrm{SO}_{4}\right)_{3} \cdot(14-18) \mathrm{H}_{2} \mathrm{O}$ solutions. Stomatal variables obtained from the $\mathrm{NaCl}$ treatments were analyzed in a $2 \times 5$ factorial scheme, where data from the adaxial and abaxial surfaces of leaves was combined with five concentrations of $\mathrm{NaCl}$ : 0, 50, 100, 150 and $200 \mathrm{mM}$. Data was then submitted to ANOVA at $\mathrm{p} \leq 0.05$ and means were compared by Tukey test at $\mathrm{p} \leq 0.05$ with the SISVAR 5 software (Ferreira, 2011).

Furthermore, an exploratory multivariate analysis was performed on the data as well. The hierarchical clustering technique interconnects samples by their associations, producing a dendrogram, where similar samples are grouped together (Moita Neto \& Moita, 1998). To measure the similarities between the centroids of each isolate, the Euclidean distance (dissimilarity measure) was applied to all variables analyzed here. For the clustering strategy, Ward's method was adopted. The result of this analysis has been presented in a graphical form (dendrogram) that helped characterize clusters.

The K-means clustering analysis defines the number of centroids (central points in each cluster) and contributes to identifying dissimilarities in the data. The procedure followed a simple way to classify the data set through a certain number of clusters that had been fixed a priori. Two clusters were used, and the distances between their centroids were obtained by the Euclidean distance. Both multivariate analyses were performed in the Statistica 13.3 software (Statsoft, 2017).

\section{Results}

\subsection{Plant Growth}

Analyses demonstrated both shoot and root growth of popcorn seedlings to respond to $\mathrm{NaCl}$ concentrations ( $\mathrm{p} \leq$ 0.05). Salt stress was more harmful to popcorn plants than $\mathrm{Al}^{+3}$ stress (Figure 1). The shoots of IAC-125 popcorn cultivar were more responsive than the roots (Figures $1 \mathrm{~A}-1 \mathrm{~B})$. Increased $\mathrm{NaCl}$ concentrations reduced root and shoot length (Figure 1A). Shoots reached a length of $30 \mathrm{~cm}$ in the control, but the length was halved $(-50 \%)$ in treatments with $200 \mathrm{mM} \mathrm{NaCl}$ (Figure 1A). Biomass reduced to $0.53 \mathrm{~g}$, which was twice less than the biomass of the control, at a concentration of $50 \mathrm{mM} \mathrm{NaCl}$ (Figure 1B). The average biomass was three times less than that of the control at $200 \mathrm{mM} \mathrm{NaCl}$ concentration, the highest salt concentration (Figure 1B). Major differences in the responses of the root system to stress were observed starting from the concentration of $150 \mathrm{mM} \mathrm{NaCl}(\mathrm{Figure}$ 1B).

No significant responses of root and shoot length could be verified to $\mathrm{Al}^{+3}$ concentrations (Figure 1C). Only root fresh mass responded to $\mathrm{Al}^{+3}$ stress $(\mathrm{p} \leq 0.05)$, where the responses were more prominent to concentrations higher than $160 \mu \mathrm{M}$ (Figure 1D).

Inhibition (\%) of fresh shoot mass was observed at a concentration of $200 \mathrm{mM} \mathrm{NaCl}$, and it doubled as compared to the treatment with $150 \mathrm{mM} \mathrm{NaCl}$ (Figure 2A). At other concentrations, values ranged from 50 to $70 \%$ inhibition, confirming a significant reduction in biomass gain by IAC-125 popcorn plants (Figure 2A). Inhibition was verified in the root system for 50 and $100 \mathrm{mM} \mathrm{NaCl}(20 \%), 150 \mathrm{mM} \mathrm{NaCl}(50 \%)$, and $200 \mathrm{mM} \mathrm{NaCl}(72 \%)$ (Figure 2B), confirming major damages to the root systems as was observed at $150 \mathrm{mM} \mathrm{NaCl}$. Shoot length significantly varied with up to $40 \%$ inhibition at concentrations between 50 and $200 \mathrm{mM} \mathrm{NaCl}$ (Figure 2C). In the root system, a 32\% inhibition was recorded (Figure 2D).

It was not possible to obtain inhibition values $(\%)$ for shoots at the different $\mathrm{Al}^{+3}$ concentrations. Seedlings responded to $\mathrm{Al}^{+3}$ stress with a small increase in shoot variables, while showing negative inhibition values. However, the root length was inhibited by $40 \%$ with $80 \mu \mathrm{M} \mathrm{Al}_{2}\left(\mathrm{SO}_{4}\right)_{3} \cdot(14-18) \mathrm{H}_{2} \mathrm{O}$ and reached almost $60 \%$ inhibition at $240 \mu \mathrm{M}$ (Figure 2E). Inhibition under $\mathrm{Al}^{+3}$ stress was more prominent in root fresh mass, which was inhibited by $30 \%$ at $80 \mu \mathrm{M} \mathrm{Al}_{2}\left(\mathrm{SO}_{4}\right)_{3} \cdot(14-18) \mathrm{H}_{2} \mathrm{O}$, with the inhibition being more than double at $240 \mu \mathrm{M}$ (Figure 2F). 

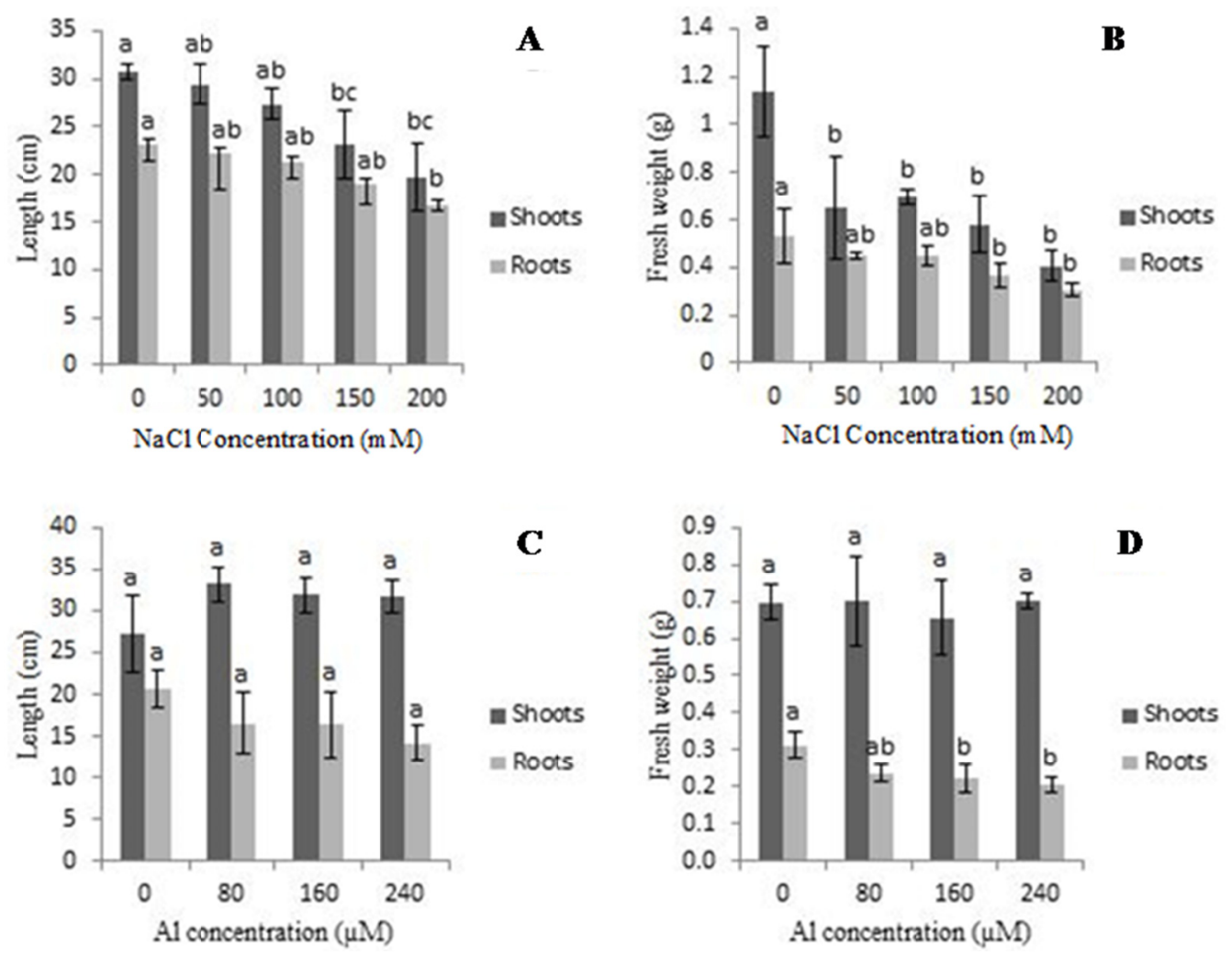

Figure 1. Length $(\mathrm{cm})$ and fresh weight $(\mathrm{g})$ of shoots and roots of popcorn plants at different concentrations of salinity ( $A$ and $B$ ) and aluminum toxicity (C and D). Means followed by the same letters do not differ as per the Tukey test $(\mathrm{p} \leq 0.05)$ 

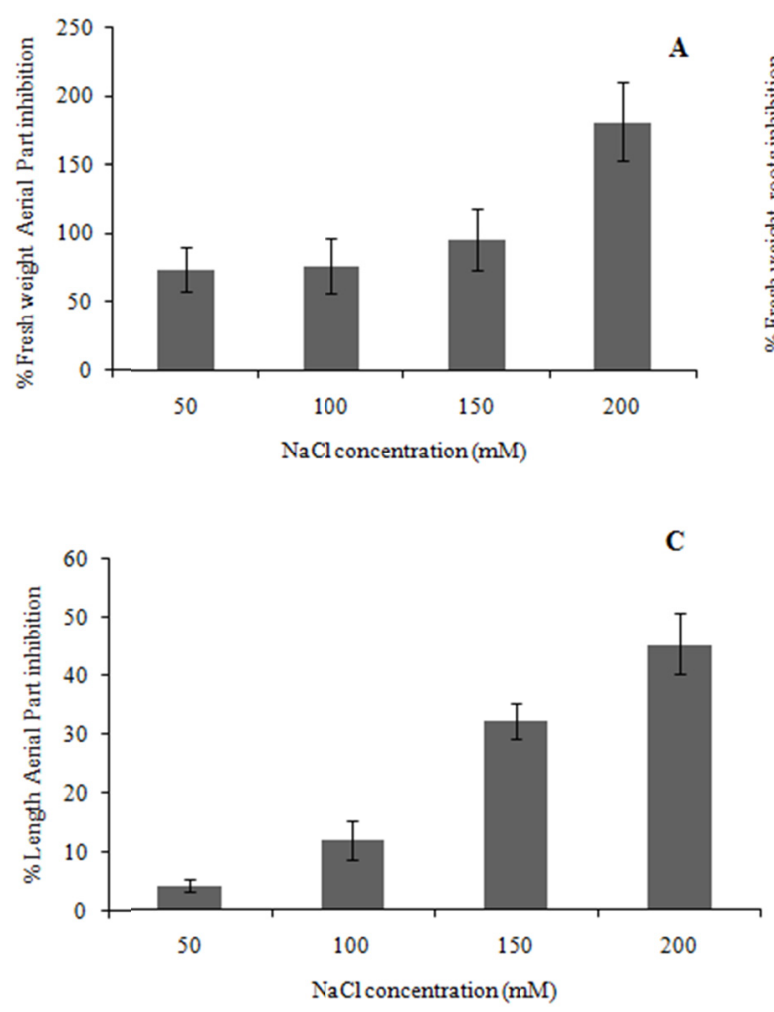

E

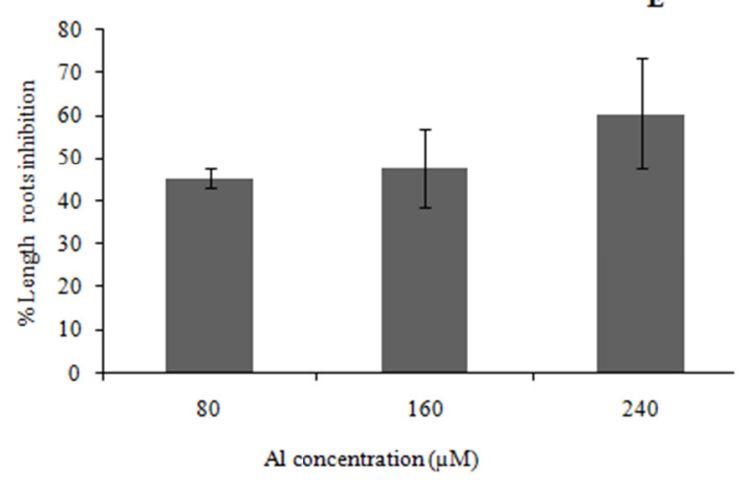

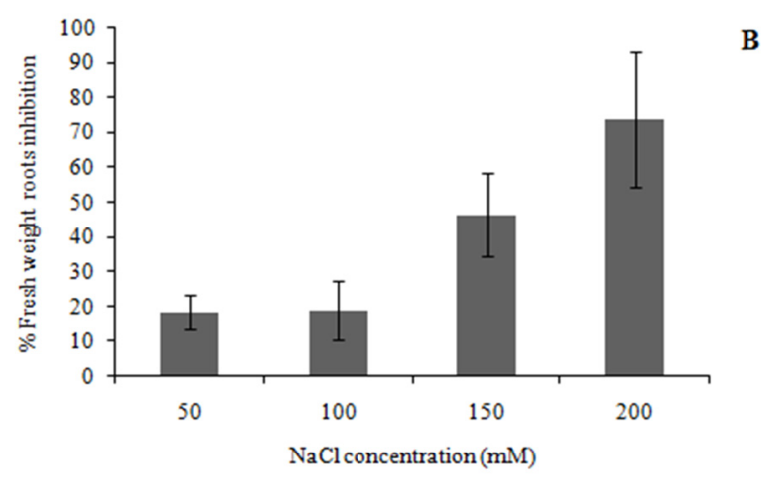

D

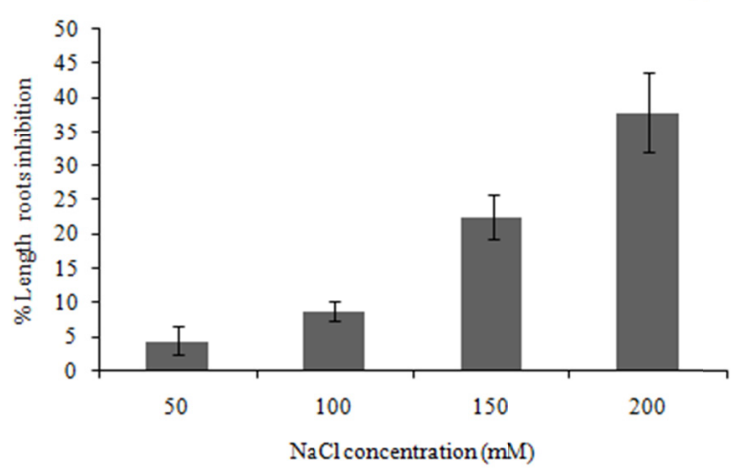

F

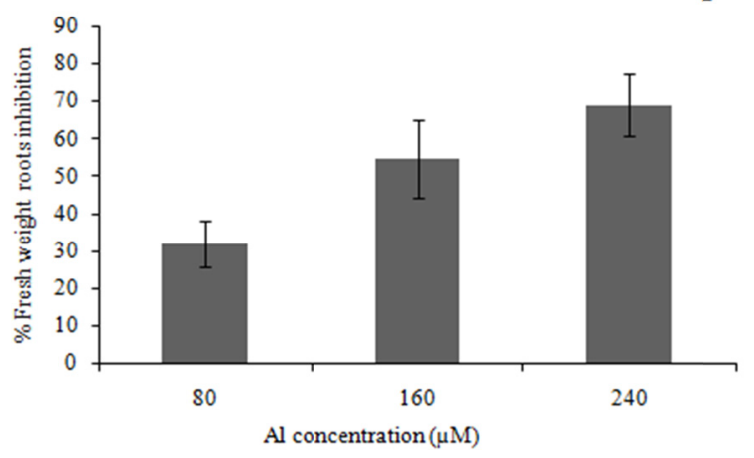

Figure 2. Inhibition (\%) of shoot fresh mass (A), root fresh mass (B), shoot growth (C), and root system growth (D) under salt stress. Inhibition (\%) of root fresh mass (E) and shoot fresh mass (F) under aluminum stress

\subsection{Stomata and Foliar Anatomy}

Genotype IAC-125 has been classified to have amphistomatic and with paracytic stomata. Stomatal analysis under $\mathrm{NaCl}$ stress showed that only the length of the subsidiary cells did not respond to the interaction between leaf surface and $\mathrm{NaCl}$ concentrations. The other variables were statistically different $(\mathrm{p} \leq 0.05)$ (Table 1). Similar results were observed for the stomata of plants treated with $\mathrm{Al}^{+3}$ (Table 1).

Stomatal density and pore aperture were higher on the abaxial surface of leaves treated with salt; their values increased in response to increased $\mathrm{NaCl}$ concentrations; the mean values were $35.33 \%$ higher at $200 \mathrm{mM} \mathrm{NaCl}$ in comparison to those for the control (Table 1). The width of subsidiary cells on the leaf's adaxial surface differed at concentrations of $150 \mathrm{mM}(3.87 \mu \mathrm{M})$ and $200 \mathrm{mM}(3.09 \mu \mathrm{M})$ (Table 1). Aluminum concentrations did not change the density of stomata on both leaf surfaces studied here, however, a higher stomatal density was observed on the abaxial surface (Table 1). The pores remained more open in the control treatment and that with $160 \mu \mathrm{M} \mathrm{Al}^{+3}$ concentration. The width of subsidiary cells on the leaf's adaxial surface increased at concentrations 
of 160 and $240 \mathrm{Al}_{2}\left(\mathrm{SO}_{4}\right)_{3} \cdot(14-18) \mathrm{H}_{2} \mathrm{O}$; in these treatments, the mean widths were $18.83 \%$ and $8.20 \%$ greater as compared to the control (Table 1).

Table 1. Effects of salt and aluminum stresses on stomata density $\left(\mathrm{mm}^{2}\right)$, pore aperture $(\mu \mathrm{m})$, subsidiary cell length $(\mu \mathrm{m})$, and subsidiary cell width $(\mu \mathrm{m})$ in leaves of popcorn

\begin{tabular}{|c|c|c|c|c|c|c|c|c|}
\hline \multicolumn{9}{|l|}{ Salt stress } \\
\hline \multirow[t]{2}{*}{$\mathrm{NaCl}(\mu \mathrm{M})$} & \multicolumn{2}{|c|}{$\begin{array}{l}\text { Stomata density } \\
\left(\mathrm{mm}^{2}\right)\end{array}$} & \multicolumn{2}{|c|}{ Pore aperture $(\mu \mathrm{m})$} & \multicolumn{2}{|c|}{$\begin{array}{l}\text { Subsidiary cell } \\
\text { length }(\mu \mathrm{m})\end{array}$} & \multicolumn{2}{|c|}{$\begin{array}{l}\text { Subsidiary cell } \\
\text { width }(\mu \mathrm{m})\end{array}$} \\
\hline & Adaxial & Abaxial & Adaxial & Abaxial & Adaxial & Abaxial & Adaxial & Abaxial \\
\hline 0 & $15.5^{\mathrm{Aa}^{*}}$ & $16.33^{\mathrm{Ba}}$ & $1.92^{\mathrm{Aa}}$ & $1.56^{\mathrm{Ca}}$ & $18.39^{\mathrm{Aa}}$ & $20.85^{\mathrm{Aa}}$ & $12.76^{\mathrm{Aa}}$ & $15.02^{\mathrm{Aa}}$ \\
\hline 50 & $14.5^{\mathrm{Aa}}$ & $19.25^{\mathrm{ABa}}$ & $2.27^{\mathrm{Aa}}$ & $1.83^{\mathrm{Cb}}$ & $19.56^{\mathrm{Aa}}$ & $19.74^{\mathrm{Aa}}$ & $13.42^{\mathrm{Aa}}$ & $14.52^{\mathrm{Aa}}$ \\
\hline 100 & $15.2^{\mathrm{Ab}}$ & $22.25^{\mathrm{ABa}}$ & $2.32^{\mathrm{Aa}}$ & $1.91^{\mathrm{CBb}}$ & $17.16^{\mathrm{Aa}}$ & $19.77^{\mathrm{Aa}}$ & $11.95^{\mathrm{Aa}}$ & $12.83^{\mathrm{Aa}}$ \\
\hline 150 & $14.2^{\mathrm{Ab}}$ & $23.25^{\mathrm{ABa}}$ & $2.06^{\mathrm{Aa}}$ & $2.40^{\mathrm{ABa}}$ & $19.44^{\mathrm{Aa}}$ & $19.84^{\mathrm{Aa}}$ & $9.39^{\mathrm{Ab}}$ & $13.26^{\mathrm{Aa}}$ \\
\hline 200 & $18.9^{\mathrm{Ab}}$ & $25.33^{\mathrm{Aa}}$ & $2.34^{\mathrm{Aa}}$ & $2.50^{\mathrm{Ab}}$ & $17.32^{\mathrm{Aa}}$ & $18.27^{\mathrm{Aa}}$ & $9.85^{\mathrm{Aa}}$ & $12.92^{\mathrm{Aa}}$ \\
\hline \multicolumn{9}{|c|}{ Aluminum stress } \\
\hline \multirow[t]{2}{*}{$\mathrm{Al}_{2} \mathrm{SO}_{4}(\mathrm{mM})$} & \multicolumn{2}{|c|}{$\begin{array}{l}\text { Stomata density } \\
\qquad\left(\mathrm{mm}^{2}\right)\end{array}$} & \multicolumn{2}{|c|}{ Pore aperture $(\mu \mathrm{m})$} & \multicolumn{2}{|c|}{$\begin{array}{l}\text { Subsidiary cell } \\
\text { length }(\mu \mathrm{m})\end{array}$} & \multicolumn{2}{|c|}{$\begin{array}{l}\text { Subsidiary cell } \\
\text { width }(\mu \mathrm{m})\end{array}$} \\
\hline & Adaxial & Abaxial & Adaxial & Abaxial & Adaxial & Abaxial & Adaxial & Abaxial \\
\hline 0 & $12.83^{\mathrm{Ab}}$ & $24.33^{\mathrm{Aa}}$ & $3.22^{\mathrm{Aa}}$ & $2.63^{\mathrm{Aa}}$ & $35.14^{\mathrm{Aa}}$ & $33.39^{\mathrm{Aa}}$ & $30.20^{\mathrm{Aa}}$ & $23.25^{\mathrm{ABb}}$ \\
\hline 80 & $13.75^{\mathrm{Ab}}$ & $20.83^{\mathrm{Aa}}$ & $2.25^{\mathrm{Ba}}$ & $1.94^{\mathrm{Aa}}$ & $34.79^{\mathrm{Aa}}$ & $40.41^{\mathrm{Aa}}$ & $30.46^{\mathrm{Aa}}$ & $20.55^{\mathrm{Bb}}$ \\
\hline 160 & $11.2^{\mathrm{Ab}}$ & $19.16^{\mathrm{Aa}}$ & $3.26^{\mathrm{Aa}}$ & $2.17^{\mathrm{Ab}}$ & $37.42^{\mathrm{Aa}}$ & $40.32^{\mathrm{Aa}}$ & $35.48^{\mathrm{Aa}}$ & $28.81^{\mathrm{Ab}}$ \\
\hline 240 & $14.0^{\mathrm{Ab}}$ & $19.41^{\mathrm{Aa}}$ & $2.77^{\mathrm{ABa}}$ & $2.05^{\mathrm{Ab}}$ & $38.04^{\mathrm{Aa}}$ & $40.11^{\mathrm{Aa}}$ & $32.94^{\mathrm{Aa}}$ & $28.62^{\mathrm{Aa}}$ \\
\hline
\end{tabular}

Note. ${ }^{*}$ Means followed by uppercase differ significantly among stresses concentrations in the same column and means followed by lowercase differ significantly among adaxial and abaxial surface in the same line by the Tukey test $(\mathrm{p} \leq 0.05)$.

Multivariate analysis of stomatal data revealed a dendrogram that divided data into two groups. The first group comprised of the two lowest concentrations of salt $(0$ and $50 \mathrm{mM})$, confirming similar plant response to these treatments; the second group included other concentrations (i.e., 100, 150, and $200 \mathrm{mM}$ ). The $150 \mathrm{mM} \mathrm{NaCl}$ concentration remained isolated (Figure 3A). The K-means-based clustering method revealed a higher stomatal density and pore aperture in the second group, while the opposite was verified for the first group. However, stomata were smaller, and their subsidiary cells were shorter in the group treated with the highest concentrations of salt (Figure 3B).

Two groups were also formed for plants treated with aluminum via multivariate analysis: the first comprised of the control and the treatment with $80 \mu \mathrm{M} \mathrm{Al}^{+3}$ (Figure 3C) and the second comprised of the treatments with the highest concentrations (i.e., 160 and $240 \mu \mathrm{M} \mathrm{Al}_{2}\left(\mathrm{SO}_{4}\right)_{3} \cdot(14-18) \mathrm{H}_{2} \mathrm{O}$ ) (Figure 3C). Dissimilarity was higher in the second group, confirming differences in stomatal responses to the treatments. The K-means clustering method revealed a higher stomatal density in group 1 as compared to that in group 2 on both leaf surfaces (Figure 3D). The opposite was observed for stomatal pore aperture with respect to the leaf surface. The stomata were observed to open on the adaxial surfaces of the leaves of IAC-125 popcorn plants in the presence of the highest concentrations of $\mathrm{Al}^{+3}$ and remain close on the abaxial surfaces in the presence of the lowest concentrations. However, stomata were larger, and their subsidiary cells were longer in the group treated with higher concentrations of $\mathrm{Al}^{+3}$ (Figure 3D). 

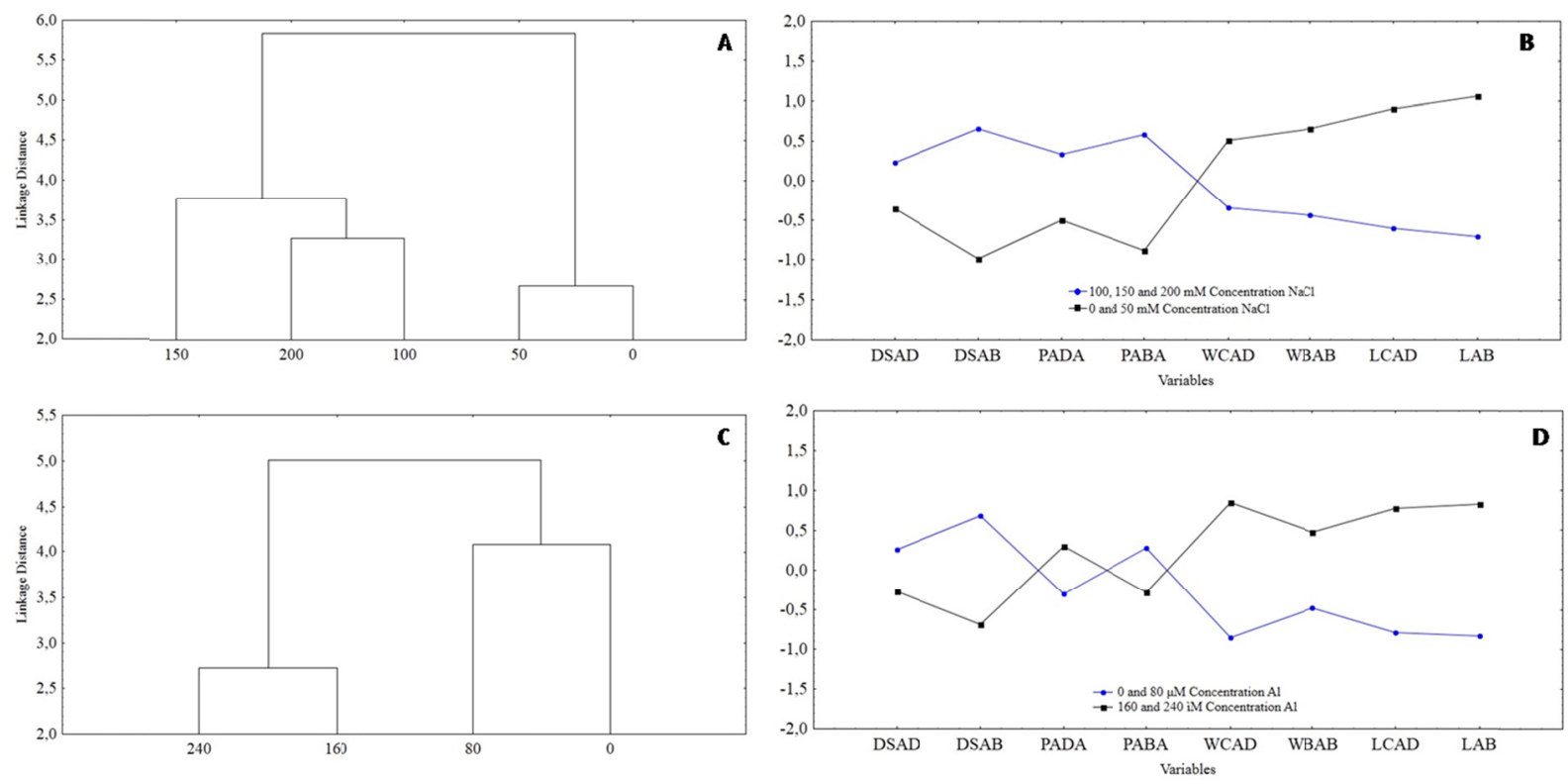

Figure 3. Morphometric measurements of stomata by Ward's methods and K-means graphs. (A) NaCl-stress dendrogram, (B) NaCl-stress K-means, (C) Al-stress dendrogram, (D) Al-stress K-means. Stomata density adaxial (DSAD); Stomata density abaxial (DSAB); Pore aperture adaxial (PADA); Pore aperture abaxial (PABA); Subsidiary cell width adaxial (WCAD); Subsidiary cell width abaxial (WBAB); Subsidiary cell length adaxial (LCAD); Subsidiary cell length abaxial (LAB)

Plants submitted to salt stress had longer subsidiary cells, mainly on the leaf's abaxial surface (Figure 4B). Morphology of stomata changed mainly under $\mathrm{Al}^{+3}$ stress in both leaf surfaces (Figures 5A-5B). Subsidiary cells missed a bilateral symmetry in comparison to the control, and thus, presented a triangular shape. These alterations in morphology were verified in both leaf surfaces treated with $160 \mu \mathrm{M} \mathrm{Al}_{2}\left(\mathrm{SO}_{4}\right)_{3} \cdot(14-18) \mathrm{H}_{2} \mathrm{O}$.

Foliar tissues of IAC-125 popcorn plants presented round-shaped epidermal cells with a thin layer of cuticle 9 after initial treatment with $\mathrm{NaCl}(0 \mathrm{mM})$ (Figure 6A). Parenchyma presented three to four cell layers that were beginning to differentiate into the palisade and laconic parenchyma with large cell spaces (Figure 6A). Anatomical alterations in leaves of plants treated with $50 \mathrm{mM} \mathrm{NaCl}$ were not observed (Figure 6B). As in the case of $100 \mathrm{mM} \mathrm{NaCl}$, cell disruption was witnessed mainly in the parenchyma and epidermis that had decreased cell spaces (Figure 6C); parenchyma cells became larger with their chloroplasts pushed to the side. This change intensified with increased concentrations of $\mathrm{NaCl}$, whereby a more prominent reduction of the epidermis occurred in plants treated with $150 \mathrm{mM}$ (Figure 6D) and $200 \mathrm{mM}$ (Figure 6E) $\mathrm{NaCl}$. In addition, it was verified that there were fewer layers of parenchyma in the two tissue sections analyzed here (Figures 6D-6E) and a decrease in cell space due to which the cells remained close together. Xylem was practically unaltered in comparison to the phloem (Figures 6D-6E). At the end of the experiment, leaves were extremely dehydrated; they showed rupture and contraction of the tissues, mainly in the epidermis and parenchyma.

Foliar tissues of plants treated with $\mathrm{Al}_{2}\left(\mathrm{SO}_{4}\right)_{3} \cdot(14-18) \mathrm{H}_{2} \mathrm{O}$ initially presented round-shaped epidermal cells without a cuticle $(0 \mu \mathrm{M})$ (Figure $7 \mathrm{~A})$. Parenchyma presented three to four cell layers that were beginning to differentiate into the palisade and laconic parenchyma with large cell spaces (Figure 7A) — a response similar to that shown by the group of plants under salt stress. Tissue arrangement changed at $80 \mu \mathrm{M}$ concentration, mainly in the parenchyma and epidermis (Figure 7B). Disruption of cells, parenchyma, and conductive vessels occurred at a salt concentration of $160 \mu \mathrm{M}$ (Figure 7C). Fewer epidermal and parenchymal cells were witnessed at 240 $\mu \mathrm{M}$ (Figure 7D). 

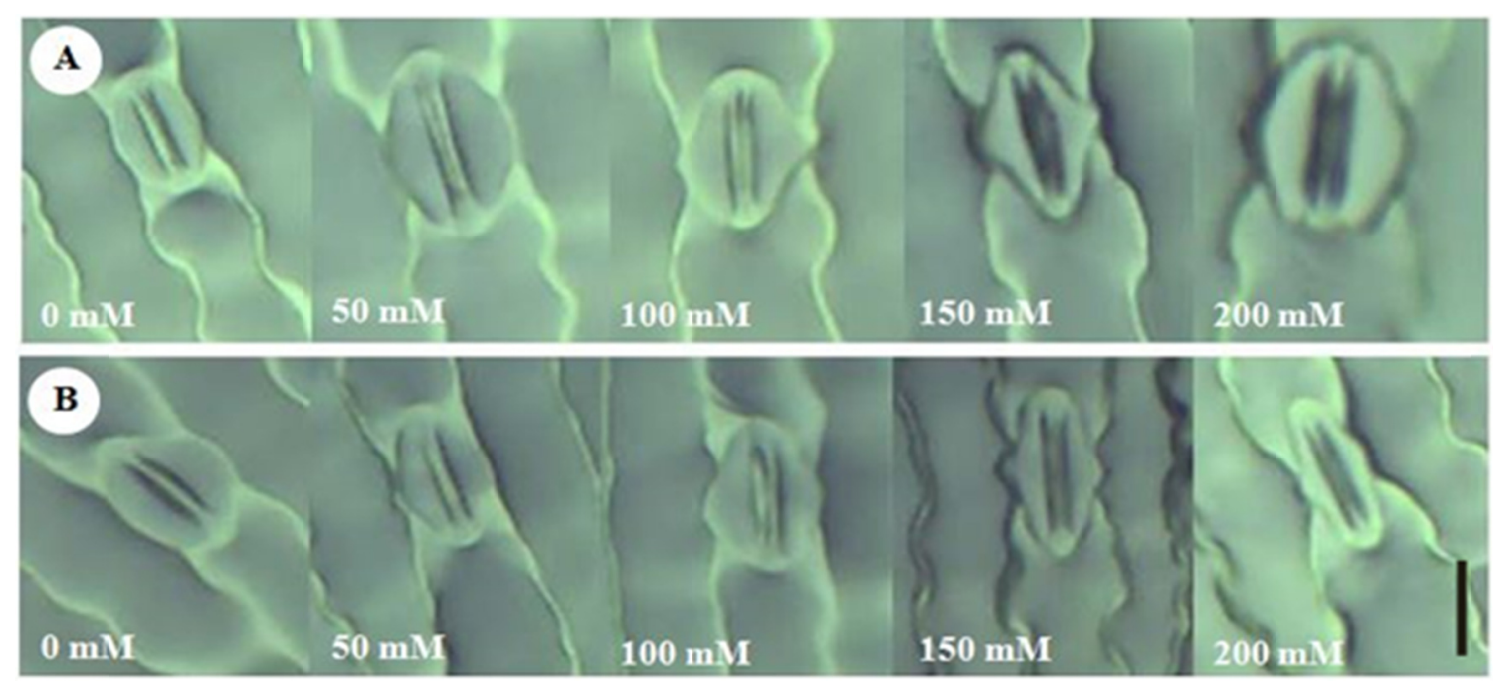

Figure 4. Differing stomatal apertures in response to $\mathrm{NaCl}$ concentrations on the adaxial (A) and abaxial (B) epidermal surfaces. Bar $=20 \mu \mathrm{m}$

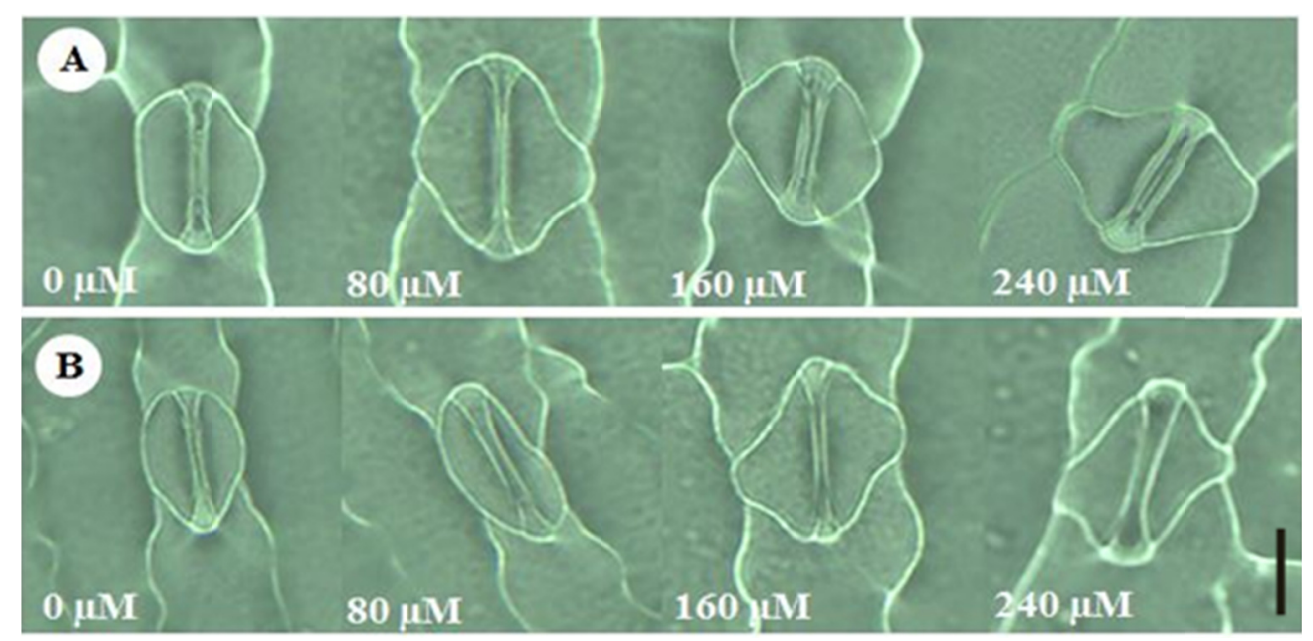

Figure 5. Differing stomatal apertures in response to $\mathrm{Al}_{2}\left(\mathrm{SO}_{4}\right)_{3}$ concentrations on the adaxial (A) and abaxial (B) epidermal surfaces. Bar $=20 \mu \mathrm{m}$ 

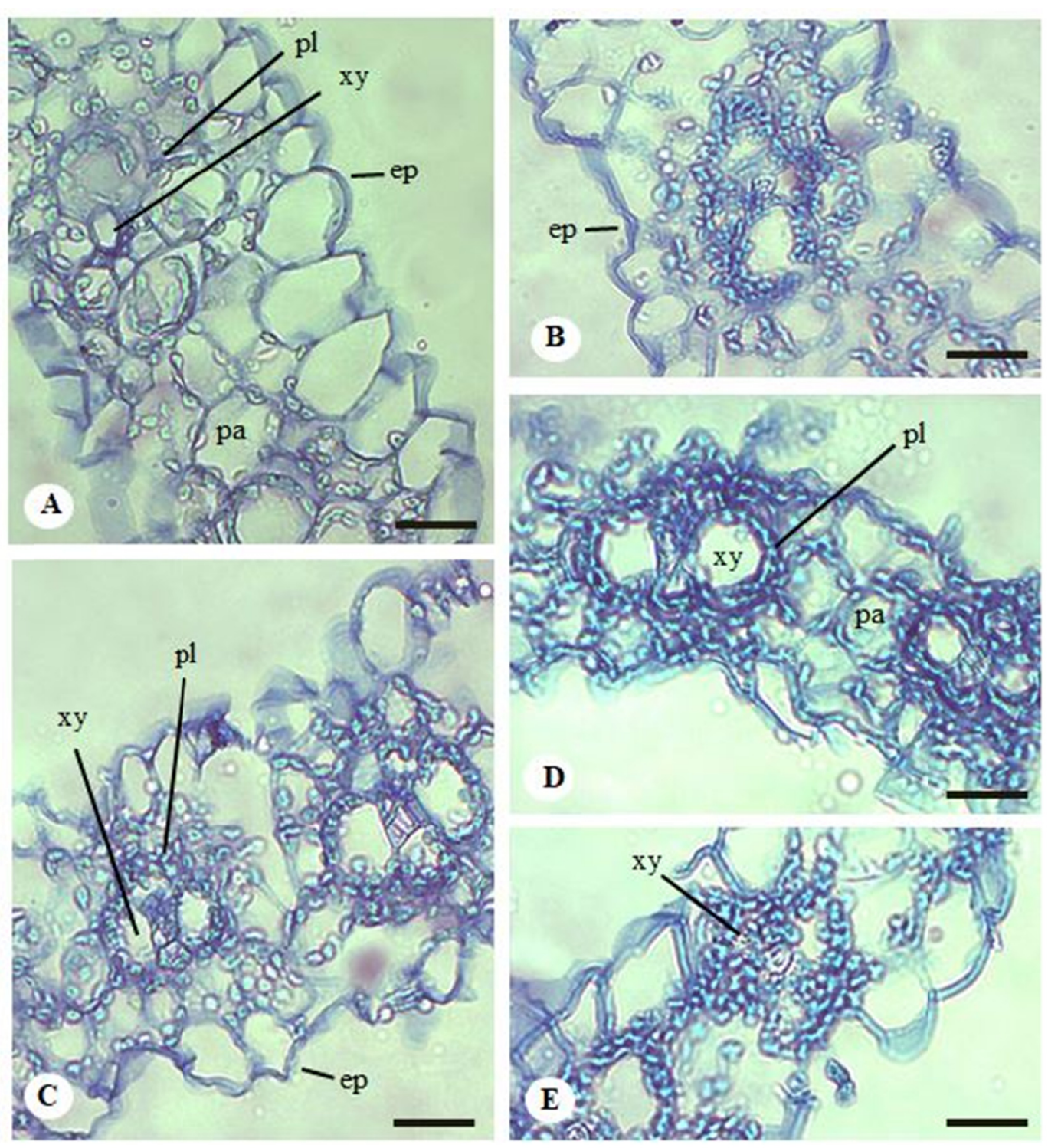

Figure 6. Cross-sections of popcorn tissues subjected to different concentrations of $\mathrm{NaCl}$ : $0 \mathrm{mM}$-control (A), 50 $\mathrm{mM}$ (B), $100 \mathrm{mM}$ (C), 150 (D), and $200 \mathrm{mM}$ (E). Ep: epidermis, Pl: phloem, Pa: parenchyma, Xy: xylem.

Bars $=20 \mu \mathrm{m}$ 


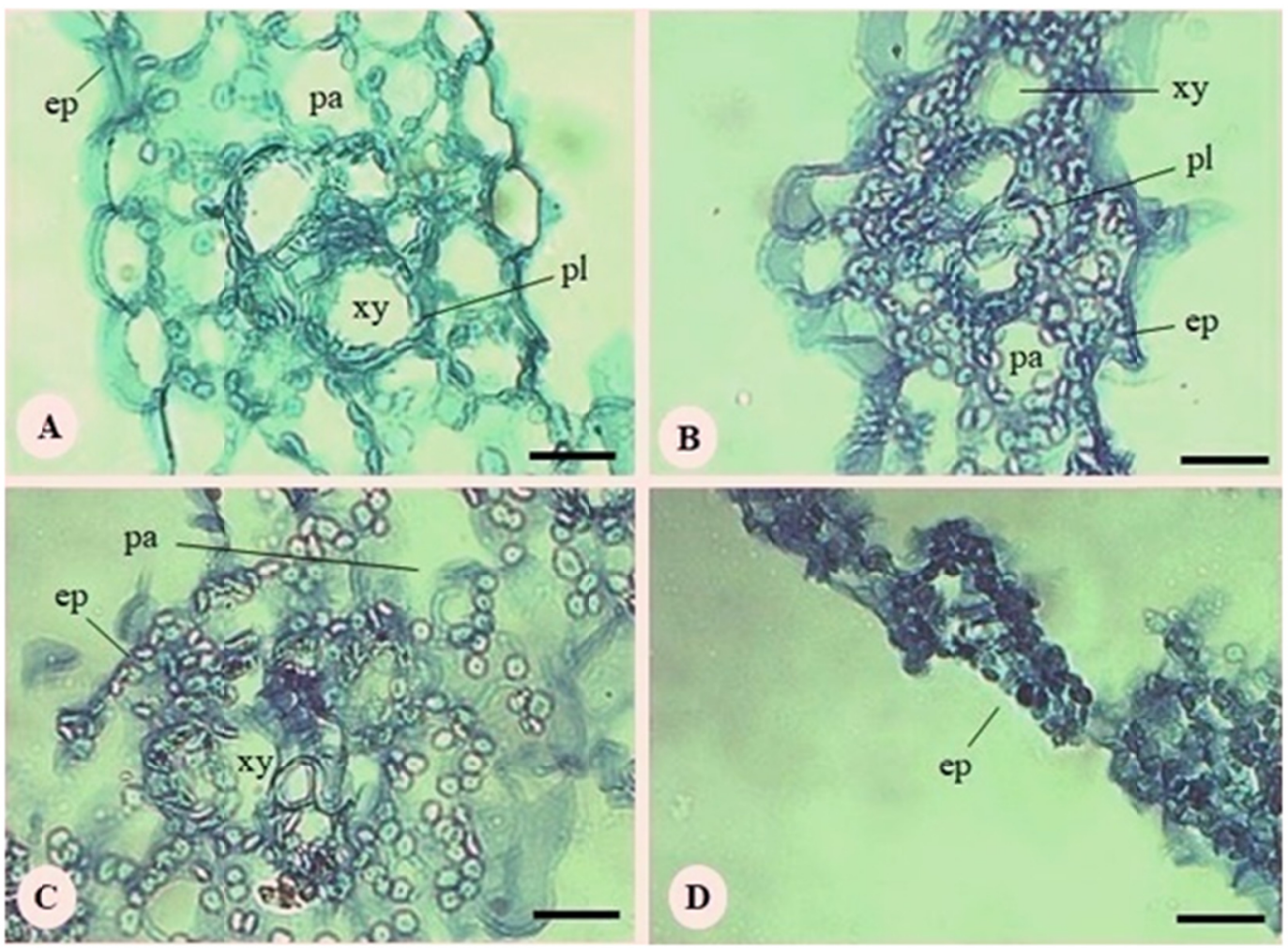

Figure 7. Cross-sections of popcorn tissues subjected to different concentrations of $\mathrm{Al}_{2}\left(\mathrm{SO}_{3}\right)_{3}: 0 \mathrm{mM}$-control (A), 80 mM (B), 160 mM (C), and 240 mM (D). Ep: epidermis, Pl: phloem, Pa: parenchyma, Xy: xylem.

Bars $=20 \mu \mathrm{m}$

\section{Discussion}

\subsection{Plant Growth}

Soil salinity can result from natural processes, such as weathering of rocks that releases magnesium and calcium ions, as well as magnesium chlorides, or by the deposition of oceanic salt brought by rainwater (Parihar et al., 2015). However, burnings, deforestation, and unbalanced fertilization have contributed significantly to the salinization of soils in recent years (Parihar et al., 2015). The main consequence is the decrease in crop yield or impediments to cropping in affected agricultural areas. In emerging countries with low-tech agriculture, salinity harms the productive sector of popcorn (Paula et al., 2010) and other crops in the short and long-term.

Firstly, it was expected that salt stress will damage shoots and roots of the IAC-125 Popcorn. This hypothesis was confirmed with the observation of major damages to the growth and biomass of shoots. According to FAO (1985), plants are classified for salt tolerance as: sensitive (S) — stress symptoms occurring at low salinity $(>0.90$ $\mathrm{dSm}^{-1} \mathrm{EC}$ ); moderately sensitive (MS) — plants that manifest stress symptoms at $>1.40 \mathrm{dSm}^{-1} \mathrm{EC}$; moderately tolerant (MT) - plants that manifest stress symptoms at $>2.40 \mathrm{dSm}^{-1} \mathrm{EC}$; and tolerant (T) - stress symptoms occurring at high salinity $\left(>4.0 \mathrm{dSm}^{-1}\right.$ EC). The IAC-125 popcorn exhibited salt stress symptoms at $50 \mathrm{mM}(>$ $0.45 \mathrm{dSm}^{-1}$ EC) with a significant decrease in its fresh mass. Therefore, according to FAO categories, the IAC-125 popcorn is sensitive to low salt concentrations.

Ravikovitch (1973) observed that corn crops were moderately sensitive to salinity $=1.8 \mathrm{dSm}^{-1} \mathrm{EC}$. Lacerda et al. (2011) reported a decreased yield of corn plants irrigated with water at $>2.2 \mathrm{dSm}^{-1}$ EC. Oliveira et al. (2009) reported that popcorn plants presented growth retardation at an early developmental stage, when irrigated with water at $2.94 \mathrm{dSm}^{-1}$ EC. Therefore, it is evident that the need for specific practices for salinity control are necessary in the cultivation of IAC-125 popcorn, especially during the initial stages of growth, when the plant is more susceptible to salt stress.

Like common corn crops, the IAC-125 popcorn presents more damage to its shoots than roots (Garcia et al., 2007; Oliveira et al., 2009). In addition, it has been verified that biomass gains decrease in comparison to the length of shoots and roots, which is attributable to cell multiplication being more affected than cell elongation. 
Munns (1993) reported that the presence of salt in the soil solution reduces growth of leaves than roots. Parihar et al. (2015) proposed a theory to explain such symptoms, whereby $\mathrm{Na}^{+}$and $\mathrm{Cl}^{-}$ions are initially deposited in the vacuole of the cells, but rapidly leak into the cytoplasm after excess accumulation, which impairs the activity of several enzymes (Boscolo et al., 2003). These ions can accumulate in the cell wall causing a dehydration of tissues and cells. The $\mathrm{Cl}^{-}$ion may be more dangerous because it impairs photosynthesis in leaves by destroying chlorophylls (Tavakkoli, Rengasamy, \& McDonald, 2010).

Aluminum is common in tropical and sub-tropical soils. More than $30 \%$ of the world's soils are classified as acidic (FAO, 2015), while more than $50 \%$ of the agricultural land is acidic $(\mathrm{pH} \leq 5.5)$. The $\mathrm{Al}^{+3}$ ions absorbed by plants are predominantly present in their root systems because they perform their growth inhibitory function in the root elongation zone (Batista et al., 2013). Aluminum may interfere with the polar transport of auxins, mainly affecting the formation of lateral roots that are important for nutrient uptake. In addition, calluses formation may occur due to the ability of $\mathrm{Al}^{+3}$ to combine with the pectic matrix of root cells (Horst, Wang, \& Eticha, 2010).

This study also revealed a slight increase in the length and fresh mass of shoots treated with $\mathrm{Al}^{+3}$ in comparison to the control. Although $\mathrm{Al}^{+3}$ is considered to be toxic to plants, some studies have revealed that concentrations up to $10 \mathrm{mg} \mathrm{L}^{-1}$ can benefit some plant species by increasing their shoot dry masses (Hartwig et al., 2007; Mukhopadyay et al., 2012). This positive effect can be due to the enhanced iron (Fe) solubility and availability at higher concentrations of $\mathrm{Al}^{+3}$ that, in turn, favors the growth of popcorn plants (Sun et al., 2007). Aluminum is hydrolyzed in the soil solution; the hydrogen ions thus released acidify the soil (Colombo, Palumbo, He, Pinton, \& Cesco, 2014). In this way, argyles containing iron oxides (goethite) may assume positive charges that impede Fe adsorption, making the Fe soluble, and thus, available (Colombo et al., 2014). For corn crop, $10 \mathrm{mM} \mathrm{Fe}$ is insufficient for good plant development because it reduces plant growth drastically by causing oxidative damage. In such situations, corn plants enhance the activity of peroxidase and catalase enzymes to mitigate stress (Sun et al., 2007).

Iron is essential for leaves to carry out photosynthesis, mainly via the photosystem I, since it is a part of the structure of the ferredoxin enzyme, which reduces NADP ${ }^{+}$to NADPH (Briat, Curie, \& Gaymard, 2007). Iron is also required for the synthesis of chlorophyll and protein complexes in chloroplasts. This suggest since it the small increase in shoots of popcorn seedlings treated with $\mathrm{Al}^{+3}$. Although popcorn plants may benefit by increased amounts of Fe, such responses are only limited because excess Fe may cause tissue toxicity (Briat et al., 2007; Sun et al., 2007); this aspect should be evaluated in further studies.

On the contrary, $\mathrm{Al}^{+3}$ has been reported to be toxic to the root system of popcorn plants, indicating that responses to different $\mathrm{Al}^{+3}$ concentrations vary according to the plant organs. The transport and accumulation of a nutrient can vary according to metabolism and extent of stress (Briat et al., 2007). In some plant species, most of the absorbed Fe is trapped in the roots. It was observed that $70 \%$ of all Fe absorbed by Psidium guajava $\mathrm{L}$. was trapped in its roots with increasing concentrations of $\mathrm{Al}^{+3}$. Biomass analysis for this species revealed that a gain in the fresh mass of leaves and stems occurred in the presence of up to $44 \mu \mathrm{M}$ aluminum. However, higher $\mathrm{Al}^{+3}$ concentrations caused greater $\mathrm{Fe}$ accumulation in the roots, which damaged the growth of plants (Salvador, Moreira, Malavolta, \& Cabral, 2010).

Opposing findings were reported in a study on Camellia sinensis (L.) O. Kuntze, where concentrations higher than $100 \mu \mathrm{M} \mathrm{Al}^{+3}$ impeded $\mathrm{Fe}$ uptake by roots. The authors confirmed the presence of $\mathrm{Fe}$ and $\mathrm{Al}^{+3}$ with the help of a hematoxylin dye, which indicated the presence of $\mathrm{Fe}$ with a black color and $\mathrm{Al}^{+3}$ with violet color after a chemical reaction. Violet was observed to be the predominant color in the roots at concentrations higher than 100 $\mu \mathrm{M} \mathrm{Al}^{+3}$ (Mukhopadyay et al., 2012). Therefore, lower concentrations of Fe did not stop root growth in this species. This result also indicates that plant responses to stress vary according to plant species and even their genotypes, as well as with the interactions of plants with their external environment. The triple hybrid corn cultivar, AS-3466, responds to concentrations above $100 \mu \mathrm{M} \mathrm{Al}^{+3}$ by reducing its dry mass and seedling length during the early stages of its growth (21 days after sowing) with the losses being more evident in shoots than in the roots (Batista et al., 2013). These results are in contrast to the observations for the IAC-125 popcorn cultivar.

Results of other tests on corn crops have demonstrated that $\mathrm{Al}^{+3}$ can damage more roots than shoots (Pellet, Grunes \& Kochian, 1995; Boscolo et al., 2003; Bennet et al., 2013). In these cases, the lack of Fe in plants was not the unique reason for damages; in fact, there were other consequences of excess $\mathrm{Al}^{+3}$ : depolarization of the plasma membrane due to displacement of cations in the plasma (Singh et al., 2017); damage to root apical meristems, interference with DNA replication, cell wall deposition, and enzyme activity (Boscolo et al., 2003); hinderance to the transport of hormones, mainly cytokinin and auxin (Sade et al., 2016); and impaired absorption 
of various cations that are important for plant nutrition and metabolism (Singh et al., 2017). In the case of popcorn, these and other hypotheses should be tested in future experiments.

\subsection{Stomata and Foliar Anatomy}

Changes in tissue morphology, stomata, and the number of tissue layers are some plant responses to excess $\mathrm{Al}^{+3}$ or salt (Ozyiğit \& Akinci, 2009; Batista et al., 2013), in addition to severe damages to the cell membrane and organelles, including mainly chloroplasts and mitochondria (Silva, Paiva, Modolo, Nascentes, \& França, 2013). In some cases, changes in the morphometry of cells and tissues are also observed (Hu, Delgado, Zhang, \& Ma, 2005; Batista et al., 2013). An example is the reduction of cuticle thickness and the change in the number of layers in the palisade and lacunar parenchyma (Hasanuzzaman et al., 2018). The same consequences are observed in both young and adult plants, such as fragility and dehydration of tissues (Ozyiğit \& Akinci, 2009; Batista et al., 2013), which interfere with plant transpiration. These disorders can interfere with physiological processes, such as photosynthesis (Ribeiro et al., 2013; Parihar et al., 2015), because $\mathrm{CO}_{2}$ assimilation is disfavored, when the stomata are closed for a long time period. Biochemical responses, such as increased enzymatic activity and production of metabolites from secondary metabolism, also cause an imbalance in the physiological processes (Boscolo et al., 2003; Richter, Erban, Kopka, \& Zörb, 2015; Pidatala et al., 2018). In addition, plants can be more susceptible to disease and insect attacks when their foliar tissues have collapsed (Silva, Alquini, \& Cavallet, 2005). Therefore, it is very important to correlate the action of these stress factors with the morpho-anatomical characteristics of plants.

It was observed that the pore aperture and the width of subsidiary cells in popcorn responded to both $\mathrm{Al}^{+3}$ and salt stress, confirming our hypothesis for this study. However, stomatal density was affected only by salt stress. Aluminum altered cell width at higher concentrations, resulting in reduced pore apertures on the adaxial surface at concentrations of 0 and $80 \mu \mathrm{M} \mathrm{Al}^{+3}$. Similar results were reported by Ozyiğit and Akinci (2009) for Urtica pilulifera; they observed morphometric differences in the pore apertures as a response to $\mathrm{Al}^{+3}$ concentrations and as per the type of branches of the plant evaluated for this species. A solution of $200 \mu \mathrm{M} \mathrm{AlCl}_{3}$ reduced stomatal openings by $61.86 \%$ than those in the control. However, the authors reported a stomatal shape like that described for the IAC-125 cultivar here: A triangular aspect with the subsidiary cells. Smirnov, Kosyan, Kosyk, \& Taran (2014) also reported a decrease in stomatal density, especially on the adaxial surface of leaves of Fagopyrum esculentum, when submitted to $50 \mu \mathrm{M} \mathrm{Al}^{+3}$.

According to Hasanuzzaman et al. (2018), when salinity levels are high, some plants tend to keep the stomata open to assimilate more $\mathrm{CO}_{2}$ and maintain greater biomass production, however, this strategy may be disadvantageous to maintain the hydration of tissues. Stomatal opening patterns may also vary with the level of salt tolerance of plant species. Stomata of Solanum pennellii, a species tolerant to salinity, close at $100 \mathrm{mM} \mathrm{NaCl}$, while stomata of Solanum lycopersicum, a species sensitive to salinity, remain open (1.5 $\mu \mathrm{M}$ aperture) on the leaf's adaxial surface (Albaladejo et al., 2017). In this case, a mechanism of salt tolerance may be a slight opening of the stomata under stress. According to Shabala et al. (2012) plants can optimize the use of water under salinity stress. This is because the cuticular pores are around the stomata. Thus, a few little open stomata are better at preventing water loss than many closed stomata.

Stomatal density of the IAC-125 cultivar tended to increase with increased concentrations of salt in our study, as already reported by other studies on common corn crops. Final mean observations showed 16 stomata on the adaxial surface of leaves and 23 on the abaxial surface; these numbers were independent of salt concentration. Opposing results were found in other studies on corn cultivars. These differences may be due to differences between the genotypes, one is popcorn and the other is common corn. When salinity increased, cultivars, BR-201 and LW-1, had an average of 77 stomata, while cultivars, Jatinã and V-190, had an average of 89 stomata (Willadino et al., 1999). When Populus euphratica was subjected to $150 \mathrm{mM} \mathrm{NaCl}$, Rajput et al. (2017) observed a $50 \%$ increase in the number of stomata (217 on the adaxial surface) in comparison to the control.

Damage to the epidermis and parenchyma was the most evident anatomical change in leaf tissue as a response to salt and $\mathrm{Al}^{+3}$ stress. An increased number of collapsed cells that were nearing total disintegration at higher levels of stress were observed. Similar results were reported by Peixoto, Pimenta, and Cambraia (2007) in roots of Sorghum bicolor (L.) Moench that was maintained in $\mathrm{Al}^{+3}$ solution $(185 \mathrm{mM})$ for 10 days. The authors reported disintegration of epidermal tissues and external portions of the root cortex. It was proposed that these ruptures were related to the binding of $\mathrm{Al}^{+3}$ to the cell wall, which increased itsstiffness, and thus, decreased elasticity (Peixoto et al., 2007).

In certain species, salinity interferes with the thickness of parenchyma by reducing cell size and space and the number of tissue layers (Albaladejo et al., 2017). Although morphometry was not assessed in this study, it was 
observed that fewer foliar tissue layers were present along with a more prominent reduction in cell spaces due to dehydration of tissues at higher salt concentrations. A $45 \%$ decrease in the leaf thickness of Triticum aestivum $\mathrm{L}$. plants submitted to $120 \mathrm{mM} \mathrm{NaCl}$ has been recorded as well (Hu et al., 2005). Thicker leaves prevent water loss under stress conditions because thickness of leaves is partially associated with tissue hydration (Ogburn \& Edwards, 2010). In our study, it was also observed that an increase in the number of cells in the parenchyma and a reduction in cell spaces occurs in the presence of $100 \mathrm{mM}$ or higher concentrations of $\mathrm{NaCl}$. This can be attributed to the plant attempt to improve $\mathrm{CO}_{2}$ diffusion to prevent water loss (Albaladejo et al., 2017).

Our results demonstrate that conductive vessel tissues are preserved, especially in larger xylem vessels, even at high salt and $\mathrm{Al}^{+3}$ concentrations. Similar results were reported by Batista et al. (2013), who observed a reduction in the cell size of xylem and phloem in corn plants due to breakage of the cell wall. Hu et al. (2005) verified a reduction in the number of small and mid-sized conducting vessels, as well as in medium and large-sized vessels in the xylem, but these changes were not observable in the IAC-125 cultivar. A possible reason for these changes is the plant attempt to adjust the hydraulic capacity of its foliar tissue, and thus, preserve the conducting vessels by developing a more resistant xylem system under stress (Rajput et al., 2017). In this way, plants preserve their hydraulic efficiency without affecting the water and nutrient distribution.

This study revealed that $\mathrm{Al}^{+3}$ and $\mathrm{NaCl}$ can severely harm the early stages of IAC- 125 popcorn development. $\mathrm{We}$ aimed to demonstrate the effects of salt and $\mathrm{Al}^{+3}$ stresses on seedlings by simulating field conditions. In seedlings treated with $\mathrm{NaCl}$, damages were more severe in the shoots than in the roots. The shoot mass was halved even at low concentrations of $\mathrm{NaCl}$, revealing the sensitivity of IAC-125 to saline conditions. These responses are also inherent to the nature of the evaluated organs since the symptoms were observed in roots only at concentrations of $150 \mathrm{mM}$ higher for $\mathrm{NaCl}$.

Our hypotheses for $\mathrm{Al}^{+3}$-treated plants have been substantiated in part. Because of the increase in shoot size, we believe that the availability of Fe was enhanced, and therefore, more of it could assimilated by the plant. As Fe was not quantified in the plant, this hypothesis is still to be tested in future studies. This study revealed that the root system is the site most affected by $\mathrm{Al}^{+3}$ concentrations, corroborating the results of previous reports on the subject.

\section{Conclusions}

The IAC-125 popcorn cultivar plants responded to $\mathrm{Al}^{+3}$ treatments with a slight increase in their shoot heights and decrease in their root fresh masses at concentration of $160 \mu \mathrm{M}$ and higher.

Shoots responded more to salt stress than roots, where shoot fresh masses decreased by $50 \%$ in the presence of $50 \mathrm{mM}$ or higher $\mathrm{NaCl}$ concentrations.

Stomata were altered in morphometry and morphology as a result of both stress factors. Aluminum concentrations did not change stomatal density, which was higher on the adaxial surface of leaves. Greater pore aperture was observed on the adaxial surface of leaves in the control and treatments with $80 \mu \mathrm{M}$ $\mathrm{Al}^{+3}$ concentration.

Stomatal density and pore aperture increased in response to $\mathrm{NaCl}$ concentrations. The width of subsidiary cells decreased by $26.42 \%$ and $22.80 \%$ in the presence of 150 and $200 \mu \mathrm{M} \mathrm{NaCl}$ as compared to the control.

Epidermis and parenchyma were the most damaged tissues under both types of stress. Higher concentrations aggravated the disruption of cell membrane, reducing the number of parenchymal layers. Tissues of xylem and phloem were preserved, even at the highest concentrations of both salt and $\mathrm{Al}^{+3}$.

\section{References}

Acosta-Motos, J. R., Ortuño, M. F., Bernal-Vicente, A., Diaz-Vivancos, P., Sanchez-Blanco, M. J., \& Hernandez, J. A. (2017). Plant responses to salt stress: Adaptive mechanisms. Agronomy, 7(1), 18. https://doi.org/ 10.3390/agronomy7010018

Albaladejo, I., Meco, V., Plasencia, F., Flores, F. B., Bolarin, M. C., \& Egea, I. (2017). Unravelling the strategies used by the wild tomato species Solanumpennellii to confront salt stress: From leaf anatomical adaptations to molecular responses. Environmental and Experimental Botany, 135, 1-12. https://doi.org/10.1016/ j.envexpbot.2016.12.003

Ali, B., Hasan, S. A., Hayat, S., Hayat, Q., Yadav, S., Fariduddin, Q., \& Ahmad, A. (2008). A role for brassinosteroids in the amelioration of aluminium stress through antioxidant system in mung bean (Vigna radiata L. Wilczek). Environmental and Experimental Botany, 62, 153-159. https://doi.org/10.1016/ j.envexpbot.2007.07.014 
American Chemical Society. (2012). Retrieved from https://www.acs.org/content/acs/en/pressroom/newsreleases /2012/march/popcorn-the-snack-with-even-higher-antioxidants-levels-than-fruits-and-vegetables.html

Antoniazzi, D., de Souza Ferrari, M. P., Nascimento, A. B., Silveira, F. A., Pio, L. A. S., Pasqual, M., \& Magalhães, H. M. (2016). Growth regulators, DNA content and anatomy in vitro-cultivated Curcuma longa seedlings. African Journal of Biotechnology, 15(32), 1711-1725. https://doi.org/10.5897/AJB2016.15445

Arendt, E. K., \& Zannini, E. (2013). Maizes. Cereal Grains for the Food and Beverage Industries (pp. 67-115e). Woodhead Publishing. https://doi.org/10.1533/9780857098924.67

Batista, M. F., Moscheta, I. S., Bonato, C. M., Batista, M. A., Almeida, O. J. G. D., \& Inoue, T. T. (2013). Aluminum in corn plants: influence on growth and morpho-anatomy of root and leaf. Revista Brasileira de Ciência do Solo, 37(1), 177-187. https://doi.org/10.1590/S0100-06832013000100018

Bennet, R. J., Breen, C. M., \& Fey, M. V. (1985). The primary site of aluminium injury in the root of Zeamays L. South African Journal of Plant and Soil, 2(1), 8-17. https://doi.org/10.1080/02571862.1985.10634130

Boscolo, P. R., Menossi, M., \& Jorge, R. A. (2003). Aluminum-induced oxidative stress in maize. Phytochemistry, 62(2), 181-189. https://doi.org/10.1016/S0031-9422(02)00491-0

Briat, J. F., Curie, C., \& Gaymard, F. (2007). Iron utilization and metabolism in plants. Current Opinion in Plant Biology, 10(3), 276-282. https://doi.org/10.1016/j.pbi.2007.04.003

Bukatsch, F. (1972). Bemerkumgenzurdoppelfärbung: Sastrablausafranina. Mikrokosmos, 61(255), 33-36.

Cançado, G. M. A., Nogueira, F. T. S., Camargo, S. R., Drummond, R. D., Jorge, R. A., \& Menossi, M. (2008). Gene expression profiling in maize roots under aluminum stress. Biologiaplantarum, 52(3), 475-485. https://doi.org/10.1007/s10535-008-0093-5

Colombo, C., Palumbo, G., He, J. Z., Pinton, R., \& Cesco, S. (2014). Review on iron availability in soil: interaction of Fe minerals, plants, and microbes. Journal of Soils and Sediments, 14(3), 538-548. https://doi.org/10.1007/s11368-013-0814-z

Dipierro, N., Mondelli, D., Paciolla, C., Brunetti, G., \& Dipierro, S. (2005). Changes in the ascorbate system in the response of pumpkin (Cucurbita pepo L.) roots to aluminium stress. Journal of plant physiology, 162(5), 529-536. https://doi.org/10.1016/j.jplph.2004.06.008

Effa, E. B., Uwah, D. F., Iwo, G. A., Obok, E. E., \& Ukoha, G. O. (2012). Yield performance of popcorn (Zea mays L. everta) under lime and nitrogen fertilization on an acid soil. Journal of Agricultural Science, 4(10), 12. https://doi.org/10.5539/jas.v4n10p12

FAO. (2015). Status of the World's Soil Resources (SWSR)-Main Report. Food and Agriculture Organization of the United Nations and Intergovernmental Technical Panel on Soils, Rome, Italy. Retrieved from http://www.fao.org/documents/card/en/c/c6814873-efc3-41db-b7d3-2081a10ede50

Ferreira, D. F. (2011). Sisvar: A computer statistical analysis system. Ciência e Agrotecnologia, 35(6), 1039-1042. https://doi.org/10.1590/S1413-70542011000600001

Garcia, G. O., Ferreira, P. A., Vieira Miranda, G., Lima Neves, J. C., Bucker Moraes, W., \& Batista dos Santos, D. (2007). Leaf contents of cationic macronutrients and their Relationships with sodium in maize plants under saline stress. Idesia (Arica), 25(3), 93-106.

Geilfus, C. M., Ludwig-Müller, J., Bárdos, G., \& Zörb, C. (2018). Early response to salt ions in maize (Zea mays L.). Journal of Plant Physiology, 220, 173-180. https://doi.org/10.1016/j.jplph.2017.11.010

Global Popcorn Market. (2017). Retrieved from https://www.reportbuyer.com/product/4343026/global-popcornmarket-2017-2021.html

Gomes, K. R., Amorim, A. V., Ferreira, F. J., Francisco Filho, L. A., Lacerda, C. F., \& Gomes-Filho, E. (2011). Physiology and growth responses of maize subjected to salt stress in different cultivingspacings. Revista Brasileira de Engenharia Agricola e Ambiental-Agriambi, 15(4).

Hartwig, I., de Oliveira, A. C., de Carvalho, F. I. F., Bertan, I., da Silva, J. A. G., Schmidt, D. A. M., ... dos Reis, C. E. S. (2007). Associated mechanisms of aluminum tolerance in plants. Semina: Ciências Agrárias, 28(2), 219-228. https://doi.org/10.5433/1679-0359.2007v28n2p219

Hasanuzzaman, M., Shabala, L., Zhou, M., Brodribb, T. J., Corkrey, R., \& Shabala, S. (2018). Factors determining stomatal and non-stomatal (residual) transpiration and their contribution towards salinity 
tolerance in contrasting barley genotypes. Environmental and Experimental Botany, 153, 10-20. https://doi.org/10.1016/j.envexpbot.2018.05.002

Hoagland, D. R., \& Arnon, D. I. (1950). The water culture method for growing plants without soils (Vol. 347, p. 32). Agricultural Experiment Station, California, USA.

Horst, W. J., Wang, Y., \& Eticha, D. (2010). The role of the root apoplast in aluminium-induced inhibition of root elongation and in aluminium resistance of plants: A review. Annals of Botany, 106(1), 185-197. https://doi.org/10.1093/aob/mcq053

Hu, C., Delgado, J. A., Zhang, X., \& Ma, L. (2005). Assessment of groundwater use by wheat (Triticum aestivum L.) in the Luancheng Xian region and potential implications for water conservation in the northwestern North China Plain. Journal of Soil and Water Conservation, 60(2), 80-88.

Johansen, D. A. (1940). Plant microtechnique. New York: McGraw Hill.

Kapoor, D., Sharma, R., Handa, N., Kaur, H., Rattan, A., Yadav, P., .. Bhardwaj, R. (2015). Redox homeostasis in plants under abiotic stress: Role of electron carriers, energy metabolism mediators and proteinaceous thiols. Frontiers in Environmental Science, 3, 13. https://doi.org/10.3389/fenvs.2015.00013

Kraus, J. E., \& Arduim, M. (1997). Manual básico de métodosemmorfologia vegetal. Seropédica: EDUR.

Lacerda, C. F., Sousa, G. G., Silva, F. L., Guimarães, F. V., Silva, G. L., \& Cavalcante, L. F. (2011). Soil salinization and maize and cowpea yield in the crop rotation system using saline waters. Engenharia Agrícola, 31(4), 663-675. https://doi.org/10.1590/S0100-69162011000400005

Lago, C., Landoni, M., Cassani, E., Doria, E., Nielsen, E., \& Pilu, R. (2013). Study and characterization of a novel functional food: Purple popcorn. Molecular Breeding, 31(3), 575-585. https://doi.org/10.1007/ s11032-012-9816-6

Manoli, A., Trevisan, S., Quaggiotti, S., \& Varotto, S. (2018). Identification and characterization of the BZR transcription factor family and its expression in response to abiotic stresses in Zea mays L. Plant Growth Regulation, 84(3), 423-436. https://doi.org/10.1007/s10725-017-0350-8

Melo, S. C., Sa, L. E. C., de Oliveira, H. L. M., Trettel, J. R., da Silva, P. S., Gonçalves, J. E., ... Magalhães, H. M. (2017). Chemical constitution and allelopathic effects of Curcuma zedoaria essential oil on lettuce achenes and tomato seeds. Australian Journal of Crop Science, 11(7), 906-916. https://doi.org/10.21475/ ajcs.17.11.07.pne562

Moita Neto, J. M., Moita, G. C. (1998). An introduction analysis exploratory multivariate date. Química Nova, 21, 467-469.

Mukhopadyay, M., Bantawa, P., Das, A., Sarkar, B., Bera, B., Ghosh, P., \& Mondal, T. K. (2012). Changes of growth, photosynthesis and alteration of leaf antioxidativedefence system of tea [Camellia sinensis (L.) O. Kuntze] seedlings under aluminum stress. Biometals, 25(6), 1141-1154. https://doi.org/10.1007/ s10534-012-9576-0

Munns, R. (1993). Physiological processes limiting plant growth in saline soils: Some dogmas and hypotheses. Plant, Cell \& Environment, 16(1), 15-24. https://doi.org/10.1111/j.1365-3040.1993.tb00840.x

Ogburn, R. M., \& Edwards, E. J. (2010). The ecological water-use strategies of succulent plants. Advances in Botanical Research, 55, 179-225. https://doi.org/10.1016/B978-0-12-380868-4.00004-1

Oliveira, F. D. A., de Medeiros, J. F., de Oliveira, M. K., Lima, C. J. D. S., de Almeida Júnior, A. B., \& Amâncio, M. D. G. (2009). Initial development of popcorn irrigated with water of different salinity levels. Revista Brasileira de Ciências Agrárias, 4(2), 149-155. https://doi.org/10.5039/agraria.v4i2a5

Özyigit, I. I., \& Akinci, S. (2009). Effects of some stress factors (aluminum, cadmium and drought) on stomata of Roman nettle (Urtica pilulifera L.). Notulae Botanicae Horti Agrobotanici Cluj-Napoca, 37(1), 108.

Paiva, J. G. A. (2006). Vernizvitralincolor 500®: umaalternativa de meio de montagemeconomicamenteviável. Acta Bot. Bras., 20(2), 257-264. https://doi.org/10.1590/S0102-33062006000200002

Parida, A. K., \& Das, A. B. (2005). Salt tolerance and salinity effects on plants: A review. Ecotoxicology and Environmental Saafey, 60(3), 324-349.https://doi.org/10.1016/j.ecoenv.2004.06.010

Parihar, P., Singh, S., Singh, R., Singh, V. P., \& Prasad, S. M. (2015). Effect of salinity stress on plants and its tolerance strategies: A review. Environmental Science and Pollution Research, 22(6), 4056-4075. https://doi.org/10.1007/s11356-014-3739-1 
Paula, T. O. M. D., Gonçalves, L. S. A., Amaral Júnior, A. T. D., Oliveira, É. C. D., Silva, V. Q. R. D., Scapim, C. A., \& Lopes, A. D. (2010). Magnitude of the genetic base of commercial popcorn and in recommendation in Brazil. Crop Breeding and Applied Biotechnology, 10(4), 289-297. https://doi.org/10.1590/S1984-7033201 0000400002

Peixoto, P. H. P., Pimenta, D. S., \& Cambraia, J. (2007). Alterações morfológicas e acúmulo de compostos fenólicos em plantas de sorgo sob estresse de alumínio. Bragantia, 66(1), 17-25. https://doi.org/ $10.1590 / \mathrm{S} 0006-87052007000100003$

Pellet, D. M., Grunes, D. L., \& Kochian, L. V. (1995). Organic acid exudation as an aluminum-tolerance mechanism in maize (Zea mays L.). Planta, 196(4), 788-795. https://doi.org/10.1007/BF00197346

Pidatala, V. R., Li, K., Sarkar, D., Wusirika, R., \& Datta, R. (2018). Comparative metabolic profiling of vetiver (Chrysopogon zizanioides) and maize (Zea mays) under lead stress. Chemosphere, 193, 903-911. https://doi.org/10.1016/j.chemosphere.2017.11.087

Rajput, V. D., Yaning, C., Ayup, M., Minkina, T., Sushkova, S., \& Mandzhieva, S. (2017). Physiological and hydrological changes in Populus euphratica seedlings under salinity stress. Acta Ecologica Sinica, 37(4), 229-235. https://doi.org/10.1016/j.chnaes.2017.02.005

Rasband, W. S. (1997). Image J. US National Institutes of Health, Bethesda, MD.

Ravikovitch, S. (1973). Effects of brackish irrigation water and fertilizers on millet and corn. Exp. Agric., 9, 181-188. https://doi.org/10.1017/S0014479700005640

Ribeiro, M. A. Q., Almeida, A. A. F. D., Mielke, M. S., Gomes, F. P., Pires, M. V., \& Baligar, V. C. (2013). Aluminum effects on growth photosynthesis, and mineral nutrition of cacao genotypes. Journal of Plant Nutrition, 36, 1161-1179. https://doi.org/10.1080/01904167.2013.766889

Richter, J. A., Erban, A., Kopka, J., \& Zörb, C. (2015). Metabolic contribution to salt stress in two maize hybrids with contrasting resistance. Plant Science, 233, 107-115. https://doi.org/10.1016/j.plantsci.2015.01.006

Sade, H., Meriga, B., Surapu, V., Gadi, J., Sunita, M. S. L., Suravajhala, P., \& Kishor, P. K. (2016). Toxicity and tolerance of aluminum in plants: tailoring plants to suit to acid soils. Biometals, 29(2), 187-210. https://doi.org/10.1007/s10534-016-9910-z

Salvador, J. O., Moreira, A., Malavolta, E., \& Cabral, C. P. (2000). Aluminum influence on growth and nutrient accumulation by young guava plants. RevistaBrasileira de Ciência do Solo, 24(4), 787-796. https://doi.org/ $10.1590 / \mathrm{S} 0100-06832000000400011$

Santos, C. D. R., Bezerra, R. D. V., Freitas, A. D. S., Seido, S. L., Martins, L. V., Rumjanek, N., \& Xavier, G. R. (2009). Modificação de vasos de Leonard com garrafasdescartáveistipo Pet. Comunicado Técnico. Embapa Agrobiologia.

Sawazaki, E. (2001). A cultura do milhopipoca no Brasil. O agronômico, 53(2), 11-13.

Segatto, F. B., Bisognin, D. A., Benedetti, M., da Costa, L. C., Rampelotto, M. V., \& Nicoloso, F. T. (2004). Técnica para o estudo da anatomia da epiderme foliar de batata. Ciência Rural, 34(5), 1597-1601. https://doi.org/10.1590/S0103-84782004000500042

Shabala, L., Mackay, A., Tian, Y., Jacobsen, S. E., Zhou, D., \& Shabala, S. (2012). Oxidative stress protection and stomatal patterning as components of salinity tolerance mechanism in quinoa (Chenopodium quinoa). Physiologia Plantarum, 146(1), 26-38. https://doi.org/10.1111/j.1399-3054.2012.01599.x

Silva, F. A. Z. (2008). Programa ASSISTAT 7.5 Beta-Assistência Estatística (Vol. 7). Campina Grande, Brasil: Versão.

Silva, F. L. B., de Lacerda, C. F., Neves, A. L. R., de Sousa, G. G., de Sousa, C. H. C., \& Ferreira, F. J (2013). Irrigação com águas salinas e uso de biofertilizante bovino nas trocas gasosas e produtividade de feijão-de-corda. RevistaIrriga, 18(2), 304-317.

Silva, J. D. O. C., Paiva, E. A. S., Modolo, L. V., Nascentes, C. C., \& Franca, M. G. C. (2013). Removal of root apices enables study of direct toxic effects of aluminum on rice (Oryza sativa L.) leaf cells. Environmental and Experimental Botany, 95, 41-49. https://doi.org/10.1016/j.envexpbot.2013.08.001

Silva, L. M., Alquini, Y., \& Cavallet, V. J. (2005). Interrelations between plant anatomy and plant production. Acta Botanica Brasilica, 19(1), 183-194. https://doi.org/10.1590/S0102-33062005000100018 
Silva, R. C. D., Grzybowski, C. R. D. S., \& Panobianco, M. (2016). Vigour in maize seeds: influence on seedling development under conditions of salt stress. Revista Ciência Agronômica, 47(3), 491-499. https://doi.org/ 10.5935/1806-6690.20160059

Singh, S., Tripathi, D. K., Singh, S., Sharma, S., Dubey, N. K., Chauhan, D. K., \& Vaculík, M. (2017). Toxicity of aluminium on various levels of plant cells and organism: a review. Environmental and Experimental Botany, 137, 177-193. https://doi.org/10.1016/j.envexpbot.2017.01.005

Smirnov, O. E., Kosyan, A. M., Kosyk, O. I., \&Taran, N. Y. (2014).Buckwheat stomatal traits under aluminium toxicity. Modern Phytomorphology, 6, 15-18. https://doi.org/10.5281/zenodo.160386

StatsoftInc. (2017). Statistica for Windows (Computer Program Manual). Retrieved July 17, 2001, from http://www.statsoft.com

Sun, B., Jing, Y., Chen, K., Song, L., Chen, F., \& Zhang, L. (2007). Protective effect of nitric oxide on iron deficiency-induced oxidative stress in maize (Zea mays). Journal of Plant Physiology, 164(5), 536-543. https://doi.org/10.1016/j.jplph.2006.02.011

Tavakkoli, E., Rengasamy, P., \& McDonald, G. K. (2010). High concentrations of $\mathrm{Na}^{+}$and $\mathrm{Cl}^{-}$ions in soil solution have simultaneous detrimental effects on growth of faba bean under salinity stress. Journal of Experimental Botany, 61(15), 4449-4459. https://doi.org/10.1093/jxb/erq251

Willadino, L., Martins, M. H. B., Camara, T. R., Andrade, A. G., \& Alves, G. D. (1999). Response of maize genotypes to saline stress in hydroponic conditions. Scientia Agricola, 56(4), 1209-1213. https://doi.org/ $10.1590 /$ S0103-90161999000500024

\section{Copyrights}

Copyright for this article is retained by the author(s), with first publication rights granted to the journal.

This is an open-access article distributed under the terms and conditions of the Creative Commons Attribution license (http://creativecommons.org/licenses/by/4.0/). 